ISSN 0258-7122

Bangladesh J. Agril. Res. 37(3): 449-456, September 2012

\title{
PERFORMANCE EVALUATION OF FERTIGATION AND MICRONUTRIENTS ON FRUIT YIELD AND QUALITY OF SUMMER TOMATO (Lycopersicon esculentum L.)
}

\author{
M. A. RAZZAQUe AKANDA ${ }^{1}$, M. SHAHABUdDIn AHAMAD ${ }^{2}$ \\ M. S. RAHMAN ${ }^{3}$, G. M. A. HALIM ${ }^{4}$ AND M. M. HASAN ${ }^{5}$
}

\begin{abstract}
Fertigation was found technically and economically feasible for tomato cultivation in winter as well as in summer. An experiment was conducted with summer tomato (BARI Hybrid Tomato-4) having 2 drip irrigation levels with different levels of NPK and micronutrient $\left(B, Z_{n}\right.$, and $\left.M_{g}\right)$ during kharif-1 seasons of 2007 and 2008. The fertilizer levels were $N_{100} P_{55} K_{120} \mathrm{~kg} / \mathrm{ha}, \mathrm{N}_{100} \mathrm{P}_{55}$ $\mathrm{K}_{120} \mathrm{~B}_{1} \mathrm{Zn}_{4} \mathrm{Mg}_{4} \mathrm{~kg} / \mathrm{ha}, \mathrm{N}_{100} \mathrm{P}_{70} \mathrm{~K}_{140} \mathrm{~kg} / \mathrm{ha}$ and $\mathrm{N}_{100} \mathrm{P}_{70} \mathrm{~K}_{140} \mathrm{~B}_{2} \mathrm{Zn}_{6} \mathrm{Mg}_{8} \mathrm{~kg} / \mathrm{ha}$ and the irrigation levels were drip irrigation at 2 days interval and drip irrigation at 3 days interval. The highest marketable yield of summer tomato $(35.90 \mathrm{t} / \mathrm{ha}$ and $27.12 \mathrm{t} / \mathrm{ha}$ ) were obtained from the fertigation treatment with fertilizer doses of $\mathrm{N}_{100} \mathrm{P}_{55} \mathrm{~K}_{120} \mathrm{~B}_{1} \mathrm{Zn}_{4} \mathrm{Mg}_{4} \mathrm{~kg} / \mathrm{ha}$ irrigated at 2 days interval in 2007 and 2008. The cull yield was also the lowest $(2.53 \mathrm{t} / \mathrm{ha}$ and $1.15 \mathrm{t} / \mathrm{ha})$ in this treatment in both the years. The lowest tomato yield (20.50 t/ha and $18.29 \mathrm{t} / \mathrm{ha})$ were obtained from the treatment with fertilizer doses $\mathrm{N}_{100} \mathrm{P}_{70} \mathrm{~K}_{140} \mathrm{~kg} / \mathrm{ha}$ irrigated at 2 days interval where no micronutrients were used. Fruit quality parameters like TSS, Vitamin-C and $\beta$-carotene were also the highest for the best yielder. So, use of micronutrients with NPK showed a significant effect on quality fruits as well as yield of summer tomato. The best yielder treatment received $261.0 \mathrm{~mm}$ of seasonal water including an effective rainfall of $60.5 \mathrm{~mm}$ during the crop seasons. The highest BCR (4.41) was also found in the same treatment.
\end{abstract}

Keywords: Fertigation, micro-nutrients, fruit quality, net return.

\section{Introduction}

Summer tomato is a profitable crop to the farmers. Due to its profitability, cultivation of summer tomato is becoming popular and extended to the farmers in different parts of the country for the last 7-8 years. Fertigation is a new technology in Bangladesh. The system has proved its superiority over other conventional methods of irrigation especially for vegetables and fruit cultivation owing to its precise and direct application of water with soluble fertilizer at the root zone with a considerable savings in fertilizer and irrigation water.

\footnotetext{
${ }^{1 \& 5}$ Principal Scientific Officer and Scientific Officer, respectively, Spice Research Centre (SRC), Bangladesh Agricultural Research Institute (BARI), Bogra, ${ }^{3}$ Scientific Officer, IWM Division, BARI, and ${ }^{2 \& 4}$ Principal Scientific Officers, Horticulture Research Centre (HRC), BARI, Gazipur, Bangladesh.
} 
Increased growth and yield of vegetable crops under fertigation have been reported by many scientists (Bhella, 1988; Bafina et al., 1993; Malik et al., 1994; Bresler, 1997 and Razzaque et al., 2004). Fertigation in tomato and brinjal gave encouraging results in terms of yield and economic return (Razzaque et al., 2004). Mahajan and Singh (2006) stated that drip irrigation at $0.5 \times \mathrm{E}_{\mathrm{pm}}$ along with fertigation of $100 \%$ recommended nitrogen resulted an increase in fruit yield by $59.5 \%$ over control (recommended practices) inside the greenhouse and by $116.20 \%$ over control outside the green house. The drip irrigation at $0.5 \times \mathrm{E}_{\mathrm{pm}}$ irrespective of fertigation treatments saved $48.10 \%$ of irrigation water and resulted in $51.70 \%$ of higher yield as compared to recommended practice inside the green house. In drip irrigation, when water was applied in lesser amount, sugar imported by fruits via phloem become concentrated which help increase TSS content and $\mathrm{pH}$ of tomato. Greenhouse tomato fruits were found superior to fruits of open field crop in terms of fruit size, TSS content, ascorbic acid content and $\mathrm{pH}$. As summer tomato is a very high value crop, fertigation can be applied to summer tomato for higher production and return. High temperature and excessive rainfall are the main constraints for tomato production in summer and rainy seasons. To overcome these problems, poly tunnel technology should be adopted for the successful production of summer tomato (Ahmed and Hossain, 2005). Use of balanced doses of NPK with micronutrients (B, $\mathrm{Zn}$, and $\mathrm{Mg}$ ) can produce quality fruits of summer tomato.

A lot of farmers and entrepreneurs have been cultivating summer tomato under poly tunnel during the last 7-8 years. From the literature, it was found that use of micro-nutrients along with NPK has a good effect on quality fruit production of vegetables. Considering this, the experiment was undertaken to determine the effects of the application of different levels of micronutrients and two levels of drip irrigation on the yield and quality of fruits as well as the profitability.

\section{Materials and Method}

A field experiment on summer tomato (BARI Hybrid-4) was conducted under poly tunnel at IWM research field, Joydebpur, BARI, Gazipur during the kharif-1 seasons of 2007 and 2008. The soil was silty clay loam with $\mathrm{pH} 6.44$, field capacity $28.6 \%$, wilting point $14.3 \%$ (By wt. basis) and bulk density $1.51 \mathrm{gm} / \mathrm{cc}$. The experiment had the following treatment combinations.

$\mathrm{T}_{1}=$ Drip irrigation at 2 days interval with fertilizer doses $\mathrm{N}_{100} \mathrm{P}_{55} \mathrm{~K}_{120} \mathrm{~kg} / \mathrm{ha}$

$\mathrm{T}_{2}=$ Drip irrigation at 3 days interval with fertilizer doses $\mathrm{N}_{100} \mathrm{P}_{55} \mathrm{~K}_{120} \mathrm{~kg} / \mathrm{ha}$

$\mathrm{T}_{3}=$ Drip irrigation at 2 days interval with fertilizer doses $\mathrm{N}_{100} \mathrm{P}_{55} \mathrm{~K}_{120} \mathrm{~B}_{1} Z_{n_{4}}$ $\mathrm{Mg}_{4} \mathrm{~kg} / \mathrm{ha}$

$\mathrm{T}_{4}=$ Drip irrigation at 3 days interval with fertilizer doses $\mathrm{N}_{100} \mathrm{P}_{55} \mathrm{~K}_{120} \mathrm{~B}_{1} \mathrm{Zn}_{4}$ $\mathrm{Mg}_{4} \mathrm{~kg} / \mathrm{ha}$ 
$\mathrm{T}_{5}=$ Drip irrigation at 2 days interval with fertilizer doses $\mathrm{N}_{100} \mathrm{P}_{70} \mathrm{~K}_{140} \mathrm{~kg} / \mathrm{ha}$

$\mathrm{T}_{6}=$ Drip irrigation at 3 days interval with fertilizer doses $\mathrm{N}_{100} \mathrm{P}_{70} \mathrm{~K}_{140} \mathrm{~kg} / \mathrm{ha}$

$\mathrm{T}_{7}=$ Drip irrigation at 2 days interval with fertilizer doses $\mathrm{N}_{100} \mathrm{P}_{70} \mathrm{~K}_{140} \mathrm{~B}_{2} \mathrm{Zn}_{6}$ $\mathrm{Mg}_{8} \mathrm{~kg} / \mathrm{ha}$

$T_{8}=$ Drip irrigation at 3 days interval with fertilizer doses $N_{100} P_{70} K_{140} B_{2} Z_{6}$ $\mathrm{Mg}_{8} \mathrm{~kg} / \mathrm{ha}$

The highest tomato fruit yield was obtained with fertilizer doses $\mathrm{N}_{100} \mathrm{P}_{55} \mathrm{~K}_{120}$ under fertigation and irrigated at 2 days interval through drip irrigation systems (Razzaque et al., 2004). The treatments were designed based upon the above findings. $\mathrm{N}$ and $\mathrm{K}$ in the form of Urea and MP were applied with irrigation water into four splits. The total $\mathrm{P}$ in the form of TSP and other micronutrients were applied during final land preparation. Cowdung was applied at the rate of $10 \mathrm{t} / \mathrm{ha}$. The mixing ratio of fertilizer and water was 1:140 for fertigation. Seedlings of 26-28 days old were planted on 15 June 2007 and 6 July 2008 with the spacing of $55 \times 40 \mathrm{~cm}$ and the unit plot size was $2.2 \times 4.0 \mathrm{~m}$. The treatments were replicated thrice. The variety was BARI Hybrid Tomato-4. Hormone was used 3 (three) times during flowering and fruit setting stages as per recommended doses. Irrigation was applied through drip system at every 2 and 3 days interval based on treatment design meeting crop ET demand. Evaporation data was recorded from class-A pan installed nearby the experimental field. The average dripper discharge was found around 4.30 liters/hour. Coloured polythene was also inserted at a depth of $75 \mathrm{~cm}$ along the sides of the bed to protect lateral seepage from rainfall in furrows. Fertigations were done on 2 July, 18 July, 4 August, and 20 August of 2007 and 20 July, 3 August, 18 August, and 31 August of 2008 and irrigations were applied at $2 \& 3$ days interval with fresh water through drip system as per treatments. Fruits were harvested from third week of August to the End of September in both the years. The fruit quality parameters were analyzed in Post Harvest Technology Division Laboratory of BARI.

\section{Results and Discussion}

Fertigation along with the use of micronutrients affected the yield and yield contributing characters of summer tomato (BARI Hybrid Tomato- 4) which are shown in Table 1 and 2. All the yield contributing characters except plant height were influenced significantly by the application of micronutrients under different levels of fertigation treatments. The highest marketable yields of summer tomato (35.90 t/ha in 2007 and $27.12 \mathrm{t} / \mathrm{ha}$ in 2008) were obtained from fertigation treatment with fertilizer doses $\mathrm{N}_{100} \mathrm{P}_{55} \mathrm{~K}_{120} \mathrm{~B}_{1} \mathrm{Zn}_{4} \mathrm{Mg}_{4} \mathrm{~kg} / \mathrm{ha}$ irrigated at 2 days interval through drip system $\mathrm{T}_{3}$ which was about averagely $62 \%$ increase (Table 3 ) yield over control. The second year yield was some what lower than the first year due to virus infestation and hail storms. But the balanced doses of fertilizers 
$\mathrm{NPK}, \mathrm{B}, \mathrm{Zn}$, and $\mathrm{Mg}$ helped uniform growth of plants and to produce quality fruits. The sizes of the fruits were mostly uniform and the colour of the ripen/matured fruits was very much attractive in treatments where the micronutrients were applied. The average cull yield (1.84 t/ha) was the lowest in treatment $T_{3}$. The average highest cull yield (3.97 t/ha) was obtained from treatment $T_{1}$ where micronutrients were not applied. From this result, it is well understood that application of micronutrients $(\mathrm{Zn}, \mathrm{B}$, and $\mathrm{Mg}$ ) along with balanced doses of NPK has a significant effect on the quality of fruits as well as tomato yield.

The fruit quality parameters of tomato like, TSS, Vitamin-C, and $\beta$-carotene were obtained also the highest in the best yielded treatment (Table 4). Due to lack of equipment facilities, fruit colour could not be determined. The best yielded treatment $\left(\mathrm{T}_{3}\right)$ received irrigation water of $261 \mathrm{~mm}$ requiring 20 irrigations along with a seasonal effective rainfall of $60.5 \mathrm{~mm}$ (Table 5).

Table 6 shows the cost effectiveness of the system which reveals that the average net return from the summer tomato cultivation by fertigation with fertilizer doses $\mathrm{N}_{100} \mathrm{P}_{55} \mathrm{~K}_{120} \mathrm{~B}_{1} \mathrm{Zn}_{4} \mathrm{Mg}_{1} \mathrm{~kg} / \mathrm{ha}$ was Tk. 13,40,100.00 per ha and BCR was 4.41. The farmers can earn about Tk. 13,40,100.00 per ha as a net return by cultivating summer tomato with fertigation method with the balanced doses of NPK and micronutrients $(\mathrm{B}, \mathrm{Zn}$, and $\mathrm{Mg}$ ) using poly tunnel technology. Higher BCR may be achieved if potential yield is ensured.

Table 1. Effect of fertigation and use of micronutrients on the yield and yield contributing characters of summer tomato, 2007.

\begin{tabular}{c|c|c|c|c|c|c|c|c}
\hline $\begin{array}{c}\text { Treat- } \\
\text { ment }\end{array}$ & $\begin{array}{c}\text { Plant/plot } \\
(\text { no. })\end{array}$ & $\begin{array}{c}\text { Plant } \\
\text { height } \\
(\mathrm{cm})\end{array}$ & $\begin{array}{c}\text { Length } \\
\text { of fruit } \\
(\mathrm{mm})\end{array}$ & $\begin{array}{c}\text { Dia of } \\
\text { fruit } \\
(\mathrm{mm})\end{array}$ & $\begin{array}{c}\text { Unit } \\
\text { fruit wt } \\
(\mathrm{g})\end{array}$ & $\begin{array}{c}\text { Marketable } \\
\text { yield } \\
(\mathrm{t} / \mathrm{ha})\end{array}$ & $\begin{array}{c}\text { Cull } \\
\text { yield } \\
(\mathrm{t} / \mathrm{ha})\end{array}$ & $\begin{array}{c}\text { Total } \\
\text { yield } \\
(\mathrm{t} / \mathrm{ha})\end{array}$ \\
\hline $\mathrm{T}_{1}$ & 37.33 & 149.00 & 42.66 & 47.17 & 55.67 & 23.05 & 4.69 & 25.19 \\
$\mathrm{~T}_{2}$ & 32.33 & 145.13 & 42.66 & 47.07 & 55.39 & 21.28 & 4.16 & 25.44 \\
$\mathrm{~T}_{3}$ & 35.33 & 146.70 & 46.18 & 48.37 & 67.00 & 35.90 & 2.53 & 38.43 \\
$\mathrm{~T}_{4}$ & 34.00 & 160.27 & 42.42 & 46.64 & 55.33 & 27.13 & 2.49 & 29.62 \\
$\mathrm{~T}_{5}$ & 35.33 & 169.73 & 44.44 & 47.99 & 54.00 & 22.00 & 3.72 & 25.72 \\
$\mathrm{~T}_{6}$ & 37.00 & 162.27 & 43.86 & 46.59 & 53.67 & 24.05 & 4.04 & 28.09 \\
$\mathrm{~T}_{7}$ & 37.67 & 161.60 & 43.33 & 48.07 & 48.00 & 23.82 & 4.02 & 27.84 \\
$\mathrm{~T}_{8}$ & 36.67 & 155.87 & 43.22 & 47.66 & 67.33 & 23.56 & 4.00 & 27.56 \\
\hline $\mathrm{CV}$ & 4.41 & 7.28 & 6.35 & 5.23 & 16.89 & 26.66 & 18.63 & 7.60 \\
$\mathrm{LSD}$ & 2.76 & $\mathrm{NS}$ & $\mathrm{NS}$ & 4.43 & 16.87 & 11.49 & 1.36 & 3.62 \\
\hline
\end{tabular}


Table 2. Effect of fertigation and use of micronutrients on the yield and yield contributing characters of summer tomato, 2008.

\begin{tabular}{c|c|c|c|c|c|c|c|c}
\hline $\begin{array}{c}\text { Treat- } \\
\text { ment }\end{array}$ & $\begin{array}{c}\text { Plant/plot } \\
(\text { no. })\end{array}$ & $\begin{array}{c}\text { Plant } \\
\text { height } \\
(\mathrm{cm})\end{array}$ & $\begin{array}{c}\text { Length } \\
\text { of fruit } \\
(\mathrm{mm})\end{array}$ & $\begin{array}{c}\text { Dia of } \\
\text { fruit } \\
(\mathrm{mm})\end{array}$ & $\begin{array}{c}\text { Unit fruit } \\
\mathrm{wt} \\
(\mathrm{g})\end{array}$ & $\begin{array}{c}\text { Marketable } \\
\text { yield } \\
(\mathrm{t} / \mathrm{ha})\end{array}$ & $\begin{array}{c}\text { Cull } \\
\text { yield } \\
(\mathrm{t} / \mathrm{ha})\end{array}$ & $\begin{array}{c}\text { Total } \\
\text { yield } \\
(\mathrm{t} / \mathrm{ha})\end{array}$ \\
\hline $\mathrm{T}_{1}$ & 37.52 & 144.46 & 41.55 & 42.66 & 38.58 & 18.29 & 3.25 & 21.54 \\
$\mathrm{~T}_{2}$ & 36.41 & 139.86 & 42.79 & 44.16 & 39.85 & 20.26 & 2.69 & 22.95 \\
$\mathrm{~T}_{3}$ & 34.60 & 139.73 & 45.12 & 47.20 & 47.52 & 27.12 & 1.15 & 28.27 \\
$\mathrm{~T}_{4}$ & 35.30 & 145.86 & 39.92 & 46.50 & 46.44 & 25.96 & 1.76 & 27.72 \\
$\mathrm{~T}_{5}$ & 33.96 & 137.80 & 38.33 & 41.50 & 43.12 & 20.41 & 1.81 & 22.22 \\
$\mathrm{~T}_{6}$ & 34.62 & 133.66 & 37.60 & 42.76 & 46.25 & 21.96 & 2.05 & 24.01 \\
$\mathrm{~T}_{7}$ & 35.79 & 124.40 & 41.05 & 43.52 & 36.69 & 20.37 & 2.15 & 22.52 \\
$\mathrm{~T}_{8}$ & 36.20 & 128.06 & 42.12 & 44.51 & 37.68 & 24.25 & 1.96 & 26.21 \\
\hline $\mathrm{CV}$ & 15.82 & 6.99 & 5.80 & 8.46 & 16.96 & 27.90 & 19.26 & 9.20 \\
$\mathrm{LSD}$ & 2.64 & 1.33 & $\mathrm{NS}$ & 3.12 & 11.54 & 10.72 & 16.32 & 4.11 \\
\hline
\end{tabular}

Table 3. Average fruit yield of summer tomato during, 2007 and 2008.

\begin{tabular}{c|c|c|c|c}
\hline Treatments & $\begin{array}{c}\text { Marketable } \\
\text { yield (t/ha) }\end{array}$ & $\begin{array}{c}\text { Cull yield } \\
(\mathrm{t} / \mathrm{ha})\end{array}$ & $\begin{array}{c}\text { Total yield } \\
(\mathrm{t} / \mathrm{ha})\end{array}$ & $\begin{array}{c}\text { \% of yield increase } \\
\text { over control }\end{array}$ \\
\hline $\mathrm{T}_{1}$ & 19.40 & 3.97 & 23.37 & - \\
$\mathrm{T}_{2}$ & 20.77 & 3.43 & 24.20 & 0.07 \\
$\mathrm{~T}_{3}$ & 31.51 & 1.84 & 33.35 & 0.62 \\
$\mathrm{~T}_{4}$ & 26.55 & 2.31 & 28.86 & 0.37 \\
$\mathrm{~T}_{5}$ & 21.21 & 2.77 & 23.98 & 0.09 \\
$\mathrm{~T}_{6}$ & 23.01 & 3.05 & 26.06 & 0.19 \\
$\mathrm{~T}_{7}$ & 22.09 & 3.09 & 25.18 & $0.14-$ \\
$\mathrm{T}_{8}$ & 23.91 & 2.98 & 26.89 & 0.23 \\
\hline
\end{tabular}

Table 4. Analysis data (average of two years) for fruit quality parameters of summer tomato during 2007 and 2008.

\begin{tabular}{c|cccc}
\hline Treatments & T.S.S & Vitamin-C $(\mathrm{mg} / 100 \mathrm{gm})$ & $\beta$-carotene $(\mu \mathrm{gm} / 100 \mathrm{gm})$ \\
\hline $\mathrm{T}_{1}$ & 4.00 & 28.21 & 45.22 \\
$\mathrm{~T}_{3}$ & 6.20 & 32.50 & 55.38 \\
$\mathrm{~T}_{5}$ & 4.00 & 21.71 & 49.61 \\
$\mathrm{~T}_{7}$ & 4.10 & 26.00 & 46.68 \\
\hline
\end{tabular}

N.B: The treatments with micronutrients variable were considered only 
Table 5. Irrigation water applied (average of 2 years) in different treatments during the crop seasons of 2007 and 2008.

\begin{tabular}{c|c|c|c|c|c}
\hline Treatment & $\begin{array}{c}\text { Irrigation } \\
\text { (no.) }\end{array}$ & $\begin{array}{c}\text { Dripper } \\
\text { discharge } \\
\text { (liters/hr.) }\end{array}$ & $\begin{array}{c}\text { Irrigation water } \\
\text { applied } \\
(\mathrm{mm})\end{array}$ & $\begin{array}{c}\text { Effective } \\
\text { rainfall } \\
(\mathrm{mm})\end{array}$ & $\begin{array}{c}\text { Total seasonal } \\
\text { water used } \\
(\mathrm{mm})\end{array}$ \\
\hline $\mathrm{T}_{1}$ & 20 & 4.30 & 264.5 & 60.5 & 325.0 \\
$\mathrm{~T}_{2}$ & 18 & 4.30 & 242.0 & 60.5 & 302.5 \\
$\mathrm{~T}_{3}$ & 20 & 4.31 & 261.0 & 60.5 & 321.5 \\
$\mathrm{~T}_{4}$ & 18 & 4.30 & 244.0 & 60.5 & 304.5 \\
$\mathrm{~T}_{5}$ & 20 & 4.31 & 259.0 & 60.5 & 319.5 \\
$\mathrm{~T}_{6}$ & 17 & 4.30 & 242.5 & 60.5 & 303.0 \\
$\mathrm{~T}_{7}$ & 22 & 4.30 & 261.0 & 60.5 & 321.5 \\
$\mathrm{~T}_{8}$ & 18 & 4.30 & 255.5 & 60.5 & 316.0 \\
\hline
\end{tabular}

Table 6. Economic analysis of fertigation system (average of 2 years) for summer tomato cultivation (For $1000 \mathrm{~m}^{2}$ of land).

\section{A. Fixed cost}

\section{i) Cost of poly tunnel (For $1000 \mathrm{~m}^{2}$ )}

\begin{tabular}{r|l|c|c|r|r}
\hline SL. No & \multicolumn{1}{|c|}{ Item } & Quantity & $\begin{array}{c}\text { Rate } \\
\text { (Tk.) }\end{array}$ & $\begin{array}{c}\text { Total cost } \\
\text { (Tk.) }\end{array}$ & \multicolumn{1}{c}{$\begin{array}{c}\text { Cost/yr } \\
\text { (Tk.) }\end{array}$} \\
\hline 1 & 3/4" G.I pipe & $2200 \mathrm{~m}$ & 80.00 & 176000.00 & 8800.00 \\
2 & 1/2" G.I pipe & $1400 \mathrm{~m}$ & 70.00 & 98000.00 & 4900.00 \\
3 & Polythene (10 Mi- & $90 \mathrm{~kg}$ & 110.00 & 9900.00 & 9900.00 \\
& crone) & & & & \\
4 & Nylon rope & $12 \mathrm{~kg}$ & 85.00 & 1020 & 1020.00 \\
5 & Others & L S & & & 1000.00 \\
\hline \multicolumn{5}{r}{ Total (Tk.) $=$} \\
\hline
\end{tabular}

N.B.: Life of G.I pipe $=20$ years

ii) Drip irrigation cost (for $1000 \mathrm{~m}^{2}$ land area)

\begin{tabular}{|c|c|c|c|c|c|c|}
\hline SL. No & Item & Quantity & $\begin{array}{l}\text { Rate } \\
\text { (Tk.) }\end{array}$ & $\begin{array}{l}\text { Total cost } \\
(\mathrm{Tk} .)\end{array}$ & Life (yr.) & $\begin{array}{l}\text { Cost } / y r \\
\text { (Tk.) }\end{array}$ \\
\hline 1 & Fertigation tank & 8 & 600.00 & 4800.00 & 5 & 960.00 \\
\hline 2 & $1 / 2 "$ dia PVC pipe & $1600 \mathrm{~m}$ & 10.00 & 16000.00 & 5 & 3200.00 \\
\hline 3 & $2.5 \mathrm{~mm}$ dia micro tube & $700 \mathrm{~m}$ & 3.00 & 2100.00 & 3 & 700.00 \\
\hline 4 & $\begin{array}{l}\text { Drippers and } \\
\text { connectors }\end{array}$ & 4200 & 1.50 & 6300.00 & 5 & 1260.00 \\
\hline 5 & $\begin{array}{l}\text { G.I fittings and } \\
\text { support of platform }\end{array}$ & 8 & - & 25000.00 & 5 & 500.00 \\
\hline
\end{tabular}

Total fixed cost $/ y r .=$ Tk. 25,620.00+6620.00 = Tk.32,240.00 
B. Variable cost (for $1000 \mathrm{~m}^{2}$ )

\begin{tabular}{cllc}
\hline SL. No & \multicolumn{1}{c|}{ Item } & Total cost $\left(1000 \mathrm{~m}^{2}\right) \mathrm{Tk}$. \\
\hline 1 & Seedlings & 600.00 \\
2 & Land preparation & 600.00 \\
3 & Fertilizer & 1000.00 \\
4 & Hormone/pesticides & 1200.00 \\
5 & Labour & 3000.00 \\
6 & Netting & 600.00 \\
\hline \multicolumn{2}{r}{ Total (Tk) }
\end{tabular}

Total cost $/$ year $\left(\right.$ For $1000 \mathrm{~m}^{2}$ of land $)=32,240.00+7,000.00=$ Tk. 39,240.00

\section{Return}

\begin{tabular}{c|l|c}
\hline SL. No & \multicolumn{1}{|c|}{ Item } & $\begin{array}{c}\text { Total cost }\left(1000 \mathrm{~m}^{2}\right) \\
\text { Tk. }\end{array}$ \\
\hline 1 & Yield $/ 1000 \mathrm{~m}^{2}$ (ton) & 3.15 \\
2 & Price (Tk./ton) & 55000.00 \\
3 & Gross return (Tk.) $/ 1000 \mathrm{~m}^{2}$ & 173250.00 \\
4 & Total cost/year & 39240.00 \\
5 & Net return (Tk.)/1000 ${ }^{2}$ & 134010.00 \\
6 & Net return (Tk./ha) & 1340100.00 \\
\hline 7 & Benefit Cost Ratio (BCR) & $\mathbf{4 . 4 1}$ \\
\hline
\end{tabular}

Based upon the performance of the best treatment, $\mathrm{T}_{3}$

\section{Conclusion}

Summer tomato cultivation is very much profitable to the farmers. Medium and small farmers can increase their family income through summer tomato cultivation. It can create employment opportunity for rural people during the lean period as well as to meet up the nutritional deficiency. From the study results, it is revealed that satisfactory yield of summer tomato can be obtained with the balanced and lower fertilizer doses of $N_{100} \mathrm{P}_{55} \mathrm{~K}_{120} \mathrm{~B}_{1} \mathrm{Zn}_{4} \mathrm{Mg}_{4} \mathrm{~kg} / \mathrm{ha}$ irrigated at 2 days interval through drip system due to higher fertilizer use efficiency. This technology also saves fertilizer and irrigation water. The application of micronutrients showed a significant effect on quality of fruits and yield. It may be demonstrated among the farmers through DAE.

\section{References}

Bhella, H. S. 1988. Tomato response of trickle irrigation and slack polythene mulch. Journal of American Society for Horticultural Science 113 (4): 543-6. 
Bafna, A. M., S. Y. Dafader, K. K. Hade, P. V. Patel and R. S. Dhotre. 1993. Utilization of nitrogen and water by tomato under drip irrigation system. Journal of Agricultural Water Management 1 (1): 1-5.

Bresler, E. 1977. Drip irrigation principles even applicants to soil under management. Ad. Agron. 29: 343-393.

Malik, R.S.K. Kumar and A. R. Bhendari. 1994. Effect of urea application through drip irrigation system on nitrate distribution in loamy sand soils and pea yield. Journal of the Indian Society of Soil Science 42 (2); 6-10.

Mahajan, G. and K. G. Singh, 2006. Response of greenhouse to irrigation and fertigation. Agricultural Water Management 8(4): 202-206.

Razzaque, A. Akanda, M. Abdullah, M. A. Hossain and M. A. Rashid. 2004. Comparative performance of fertigation and traditional system of tomato cultivation. Bangladesh J. Agril. Res. 29(3): 2004.

Ahamed, H. and A. E. Hossain. 2005. Increase of farmers' income employment opportunity and poverty reduction through summer tomato cultivation. Paper presented on technology transfer workshop held on 15-17 March 2005. 